Корнивская В. О., Д.э.н.

ГУ «Институт экономики и прогнозирования

Национальной академии наук Украиньл»

г. Киев, Украина

DOI: https://doi.org/10.30525/978-9934-26-036-0-4

\title{
ФИНАНСОВАЯ СВОБОДА В СОВРЕМЕННОМ МИРЕ
}

Характеризуя историческую природу экономической свободы, еe наиболее последовательный пропагандист и гениальный исследователь Ф.А. Хайек в своей работе «Пагубная самонадеянность» писал: «...основы собственно современной цивилизации были заложены в античном Средиземноморье. Здесь оказались возможными торговые связи между достаточно отдаленными друг от друга регионами; и общины, позволявшие 20 
своим членам свободно применять их индивидуальные знания, получали преимущество перед общинами, где деятельность каждого из членов определялась тем, что знали все живущие в данной местности, или знаниями правителя. Насколько нам известно, именно в Средиземноморье отдельная личность впервые получила право самостоятельно распоряжаться в узаконенной сфере частной жизни» [1, с. 53]. Так зародилась свобода предпринимательства как основа эволюционной способности западного общества: свобода принимать самостоятельные экономические решения на основе своих знаний и быть ответственными за них, следуя правилам институциональной среды, установленным обычаем и государством.

Наиболее точную характеристику экономической свободы в контексте баланса взаимоотношений государство - субъект дал Милтон Фридман: «Свободный человек не будет спрашивать ни о том, что может сделать для него его страна, ни о том, что он сам может сделать для своей страны. Вместо этого он спросит: «Что я и мои соотечественники можем сделать с помощью государства» для того, чтобы нам легче было выполнять свои индивидуальные обязанности, добиваться своих отдельных целей и, прежде всего, защищать нашу свободу?» [2, с. 25]. В рыночной экономике государство - это созидатель институциональной среды для эффективной реализации экономических интересов свободных, деятельных рыночных субъектов, ставящих экономическую свободу во главу угла и готовых за нее бороться.

Неотъемлемой составляющей экономической свободы является финансовая свобода - более узкое понятие, характеризующее определенный род экономических отношений. И, тем не менее, именно ее трансформации ведут к кардинальной перестройке глубинных экономических устоев рыночного общества в условиях становления информационно-сетевой экономики.

Финансовую свободу рыночных субъектов следует рассматривать как финансовую независимость - принятие решений экономического и социального характера без финансового 
участия других субъектов. Степень финансовой свободы зависит от долгосрочного соотношения доходов и расходов, что обусловливает долгосрочные бюджетные ограничения, а также субъектный выбор альтернатив финансового поведения [3, с. 229]. Основой финансовой свободы в рыночном обществе являются накопления и эффективный инвестиционный процесс, роль государства сводится к созданию условий устойчивого экономического развития и соответствующей экономикоинституциональной среды. При этом приоритет конкуренции предполагают редкость прямого государственного участия в финансовой деятельности субъектов рынка ${ }^{1}$.

Современный глобальный кризис показал новое качество взаимосвязи государства и субъекта: инвариантность, основанную на растущей финансовой несвободе в условиях укоренения проблем бедности.

Сегодня мы является свидетелями не только предельной мобильности распространения эпидемиологического, медицинского, экономического, финансового и политического шока в мировой системе координат, но и беспрецедентности реакции государств на кризисные условия, - повсеместные локдауны продемонстрировали негибкость, авторитарность государственной политики, хрупкость экономических связей и отсутствие кризисного иммунитета у большинства рыночных субъектов, которые обнаружили значительную экономическую несамостоятельность, обусловленную растущей бедностью. Финансовая свобода, основанная на эффективных долгосрочных сбережениях, показала свою ограниченность и явную поврежденность.

Как оценить масштабы мировой финансовой несвободы, - для начала путем простого подсчета лиц, нуждавшихся в государственной финансовой помощи в течение локдаунов, вызванных коронакризисом. В 2020 году более 3,7 млрд человек (чуть меньше половины населения планеты) и 500 млн микро-, малых и

\footnotetext{
1 Такое участие является косвенным и проявляется в фискальной функции государства и налоговых обязанностях субъекта.
} 
средних предприятий во всем мире получили государственную поддержку. По данным МВФ по состоянию на сентябрь 2020 общие объемы мировой государственной поддержки реального сектора экономики (предприятий и физических лиц) составили 11,7 трлн долл, $12 \%$ ВВП [4]. Это свидетельствует о том, что возможность справляться самостоятельно с кризисными колебаниями у населения предельно мала, а накопления на случай чрезвычайных ситуаций мизерные. Деструкция накопления сегодня проявляется не только в недостаточности объемов «финансовых подушек безопасности», даже в богатых государствах с относительно устойчивым средним классом наблюдаются растущие проблемы пенсионных накоплений.

Данные американской страховой компании Northwestern Mutual подтверждают эту аргументацию [5]: 78\% американцев «существенно» или «несколько» обеспокоены обеспечением комфортного выхода на пенсию, две трети считают, что сделанных сбережений не хватит на достойную пенсионную жизнь. Каждый пятый американец (21\%) вообще не имеет накопленных пенсионных сбережений. Исследование также показало, что опасения относительно финансовой безопасности на пенсии заставляет людей работать дольше. Сегодня значительное количество работающих американцев планируют выход на пенсию в 70 лет и старше (38\%). Среди 55\% американцев, которые считают, что придется работать после достижения 65-летнего возраста, 73\% основной причиной назвали недостаточность денег, чтобы комфортно выйти на пенсию. Для тех, кто планирует работать после 65 лет, располагаемый доход (55\%) и профессиональное удовлетворение (54\%) были почти равными мотиваторами. Это существенный контраст с результатами исследования 2015 года, где основным фактором было получение удовольствия от карьеры (66\%), а затем интерес к дополнительному доходу (60\%). Последний тезис также наводит на мысль о том, что продолжаются существенные трансформации социоинституционального пространства западного общества, проявляющиеся в сдвигах в мотивациях 
профессиональной реализации, которая становится все более зависимой от факторов финансового характера, доминирование которых расширяет границы растущей финансовой несвободы.

О чем говорят эти цифры? Лишь о том, что половина населения планеты сегодня нуждается в государственном финансировании своей жизнедеятельности, поскольку деструкции процессов накопления в условиях растущей неопределенности, частых кризисов и углубляющейся социальноэкономической несбалансированности укоренили проблемы бедности, социальной неустойчивости и отсутствия социальной мобильности на долгие годы.

Современный научный дискурс по поводу данной проблематики нацелен на обоснование необходимости создания цифровых систем государственной трансфертной поддержки населения и малых предприятий в условиях учащающихся кризисов различной этиологии [4]. При этом считается, что государственная финансовая помощь становится необходимым атрибутом экономической активности. Следовательно, субъект рассматривается не иначе, как экономически несамостоятельная, зависимая единица, нуждающаяся в перманентной, инвариантной прямой взаимосвязи с государством, дающим финансовые костыли, вместо формирования здоровой, устойчивой экономической среды для свободного предпринимательства. Если такие тенденции станут императивом, то экономическая свобода перестает выполнять роль системообразующего, эволюционного фактора развития, что свидетельствует о нивелировании рыночных основ современного общества.

\section{Литература:}

1. Хайек Ф.А. Пагубная самонадеянность. Ошибки социализма / пер. с анг. Москва : Изд-во «Новости». 1992. 304 с.

2. Фридман М. Капитализм и свобода / пер. с англ. Москва : Новое издательство, 2006. 240 с.

3. Корнівська В. Трансформації інститутів фінансового посередництва в умовах становлення інформаційно-мережевої економіки: дис. ... докт. екон. наук. : 08.00.01 2019. Київ, 2019. 598 с. URL: http://ief.org.ua/wp-content/ uploads/2016/04/дисер_Корнівська.pdf. 
4. Olivia White, Anu Madgavkar, Tawanda Sibanda, Zac Townsend, and María Jesús Ramírez. COVID-19: Making the case for robust digital financial infrastructure. January 26, 2021. URL: https://www.mckinsey.com/industries/financial-services/ourinsights/covid-19-making-the-case-for-robust-digital-financial-infrastructure?cid=other-eml-alt-mgi-mck\&hdpid=2675c7b0-529f-411c84cb8ff7de35d932\&hctky=297 9573\&hlkid=dd293b9381054aada0c71d006bbee14d.

5. 1 In 3 Americans Have Less Than \$5,000 In Retirement Savings. Northwesternmutual. 2018. URL: https://news.northwesternmutual.com/2018-05-081-In-3-Americans-Have-Less-Than-5-000-In-Retirement-Saving. 